\title{
KORELASI ANTARA LITERASI BACA TULIS DAN BUDAYA DENGAN PENGUASAAN KOMPETENSI PENGETAHUAN IPS SISWA KELAS IV
}

\author{
Kadek Sri Trisna Devi ${ }^{1}$, I Made Suarjana1, Gede Wira Bayu² \\ 1 Jurusan Pendidikan Dasar, Universitas Pendidikan Ganesha, Singaraja, Indonesia \\ ${ }^{2}$ Jurusan Pendidikan Dasar, Universitas Pendidikan Ganesha, Singaraja, Indonesia \\ ${ }_{3}^{3}$ Jurusan Pendidikan Dasar, Universitas Pendidikan Ganesha, Singaraja, Indonesia
}

\begin{abstract}
Abstrak
Penelitian ini bertujuan untuk mengetahui korelasi antara: (1) literasi baca tulis dengan penguasaan kompetensi pengetahuan IPS, (2) literasi budaya dengan penguasaan kompetensi pengetahuan IPS, (3) literasi baca tulis (X1) dan budaya (X2) dengan penguasaan kompetensi pengetahuan IPS (Y) siswa kelas IV SD di gugus XIV Kecamatan Buleleng tahun pelajaran 2018/2019. Jenis penelitian ini adalah penelitian Expost facto. Populasi dari penelitian ini adalah seluruh siswa kelas IV yang berjumlah 139 orang. Sampel yang diambil dalam penelitian ini menggunakan teknik stratified proportional random sampling dengan jumlah sampel sebanyak 103 orang. Data diperoleh dengan penyebaran kuesioner literasi budaya, soal uraian literasi baca tulis, dan pencatatan dokumen penguasaan kompetensi pengetahuan IPS. Data yang diperoleh dianalisis dengan korelasi product moment sederhana dan korelasi product moment berganda. Hasil analisis deskriptif menemukan bahwa rata-rata literasi baca tulis yaitu 21.11 dengan kategori sedang, literasi budaya yaitu 92.41 dengan kategori sedang, dan penguasaan kompetensi pengetahuan IPS yaitu 68.46 dengan kategori sedang. Dari hasil uji analisis hipotesis I diperoleh rx1y (0.213) > rtabel (0.1630), uji hipotesis II diperoleh rx2y (0.525) > rtabel (0.1630), dan uji hipotesis III diperoleh $r x 1 x 2 y(0.528)>$ rtabel $(0.1630)$. Dari hasil perhitungan berarti $r$ hitung $>r$ tabel maka H0 ditolak dan H1 diterima. Dapat diambil simpulan terdapat korelasi antara: (1) literasi baca tulis dengan penguasaan kompetensi pengetahuan IPS, (2) literasi budaya dengan penguasaan kompetensi pengetahuan IPS, (3) literasi baca tulis dan budaya dengan penguasaan kompetensi pengetahuan IPS siswa kelas IV SD di gugus XIV Kecamatan Buleleng tahun pelajaran 2018/2019.
\end{abstract}

\section{Pendahuluan}

Kehidupan manusia pada abad ke-21 mengalami perubahan-perubahan yang fundamental yang berbeda dengan tata kehidupan dalam abad sebelumnya. Abad ke-21 ditandai sebagai abad keterbukaan atau abad globalisasi (Wijaya, dkk, 2016). Dikatakan abad ke-21 adalah abad yang meminta kualitas dalam segala usahaa dan hasil kerja manusia. Dengan sendirinya abad ke-21 meminta sumberdaya manusia yang berkualitas, yang dihasilkan oleh lembaga-lembaga yang dikelola secara profesional sehingga membuahkan hasil unggulan. Di abad ke 21 ini, pendidikan menjadi semakin penting untuk menjamin siswa memiliki keterampilan belajar dan berinovasi, keterampilan menggunakan teknologi dan media informasi, serta dapat bekerja, dan bertahan dengan menggunakan keterampilan untuk hidup.

Selain abad ke-21, Pesatnya perkembangan dan pemanfataan teknologi digital di berbagai bidang kehidupan manusia yang juga menimbulkan terjadinya revolusi industri 4.0 yang tengah dihadapi oleh seluruh negara di dunia dan pastinya siswa pun juga menghadapi revolusi ini. Winaya (2018:103) menyatakan, saat ini pemerintah Indonesia pun tengah fokus meningkatkan daya saing bangsa untuk dapat menghadapi revolusi industri 4.0 tersebut karena diprediksi memiliki potensi manfaat yang besar terhadap kemajuan negara. Sebagian besar pendapat mengenai potensi manfaat Industri 4.0 adalah mengenai perbaikan kecepatan fleksibilitas 
produksi, peningkatan layanan kepada pelanggan dan peningkatan pendapatan. Terwujudnya potensi manfaat tersebut akan memberi dampak positif terhadap perekonomian suatu negara.

Untuk dapat menghadapi revolusi industri 4.0 tersebut, pemerintah sudah berupaya melalui gerakan literasi nasional (GLN). Literasi adalah kemampuan membaca dan menulis (Gipayana, 2004). Dalam konteks itu, pembelajaran literasi di sekolah-sekolah menampakkan peranannya yang amat penting. GLN ini memiliki tujuan yaitu untuk menumbuhkembangkan budaya literasi yang dijalankan disetiap jenjang pendidikan khususnya pendidikan di sekolah dasar. Agar sanggup unggul dalam partisipasi dan kiprah di tengah globalisasi dan regionalisasi pada abad ke-21, pendidikan nasional kita perlu berfokus atau berporos pada literasi dasar (Saryono, dkk, 2017). Literasi dasar yang perlu dijadikan poros pendidikan kita adalah 1) literasi baca tulis, 2) literasi numerasi, 3) literasi sains, 4) literasi digital, 5) literasi finansial, 6) literasi budaya dan kewargaan. Penelitian kali ini berfokus pada literasi baca tulis dan budaya.

Membaca dan menulis merupakan literasi yang dikenal paling awal dalam sejarah peradaban manusia (Saryono, dkk, 2017). Keduanya tergolong literasi fungsional dan berguna besar dalam kehidupan sehari-hari. Dengan memiliki kemampuan baca tulis, seseorang dapat menjalani hidupnya dengan kualitas yang lebih baik. Terlebih lagi di era yang semakin modern yang ditandai dengan persaingan yang ketat dan pergerakan yang cepat.

Keupayaan membaca merupakan suatu kemahiran yang amat bernilai dan merupakan proses yang dinamik, yaitu memerlukan komunikasi yang aktif dan bermakna antara pembaca dengan penulis (Jamian, 2011). Membaca merupakan kunci untuk mempelajari segala ilmu pengetahuan, termasuk informasi dan petunjuk sehari-hari yang berdampak besar bagi kehidupan. Ketika menerima resep obat, dibutuhkan kemampuan untuk memahami petunjuk pemakaian yang diberikan oleh dokter. Jika salah, tentu akibatnya bisa fatal. Kemampuan membaca yang baik tidak sekadar bisa lancar membaca, tetapi juga bisa memahami isi teks yang dibaca (Saryono, dkk, 2017). Teks yang dibaca pun tidak hanya kata-kata, tetapi juga bisa berupa simbol, angka, atau grafik.

Berkaitan erat dengan membaca, kemampuan menulis pun penting untuk dimiliki dan dikembangkan. Kemampuan dalam menulis pada siswa dapat tercapai apabila proses pembelajaran berjalan baik dan kondusif (Widodo, dkk, 2016). Menulis merupakan salah satu kompetensi bahasa yang ada dalam setiap jenjang pendidikan, mulai tingkat prasekolah hingga perguruan tinggi. Menulis merupakan kompetensi yang sudah ada dan dimulai di jenjang Sekolah Dasar (Mundziroh, 2013). Siswa dapat mengungkapkan perasaan, ide, dan gagasannya kepada orang lain melalui kegiatan menulis narasi. Membaca dan menulis berkorelasi positif dengan kemampuan berbahasa dan penguasaan kosakata (Saryono, dkk, 2017). Masukan kata-kata dan gagasan didapat melalui membaca, sedangkan keluarannya disalurkan melalui tulisan. Seseorang yang terbiasa membaca dan menulis bisa menemukan kata atau istilah yang tepat untuk mengungkapkan suatu hal. Kemampuan seperti inilah yang membuat komunikasi berjalan dengan baik.

Untuk dapat menyerap informasi dari bacaan atau meramu ide menjadi tulisan diperlukan fokus yang baik. Dengan begitu, membiasakan diri untuk melakukan aktivitas membaca dan menulis akan meningkatkan daya konsentrasi. Di samping itu, imajinasi dan kreativitas pun akan tumbuh karena semakin banyak wawasan yang didapat dan semakin tajam cara berpikir yang terbentuk. Membaca dan menulis juga bisa dijadikan sarana hiburan yang dapat menurunkan tingkat stres. Oleh karena itu, literasi baca tulis perlu dikenalkan, ditanamkan, dan dibiasakan kepada masyarakat Indonesia, khususnya oleh para pemangku pendidikan.

Selain literasi baca tulis, literasi budaya juga sangat penting. Literasi budaya merupakan kemampuan dalam bersikap terhadap kebudayaan Indonesia sebagai identitas bangsa (Hadiansyah, dkk, 2017). Indonesia memiliki keberagaman dalam hal suku bangsa, bahasa, budaya, adat dan kebiasaan, bahkan agama dan kepercayaan. Selain itu, sebagai bagian dari dunia global, Indonesia juga mendapat pengaruh budaya dari berbagai negara sebagai 
dampak dari hubungan kerja sama yang dibangun. Akibatnya, keberagaman yang sudah ada, yang dibawa oleh tiap-tiap suku bangsa di Indonesia menjadi semakin kompleks dengan masuknya pengaruh global. Oleh karena itu, literasi budaya dan kewargaan penting diberikan di tingkat keluarga, sekolah, dan masyarakat. Literasi budaya tidak hanya menyelamatkan dan mengembangkan budaya nasional, tetapi juga membangun identitas bangsa Indonesia di tengah masyarakat global.

Kemampuan untuk memahami keberagaman dan tanggung jawab warga negara sebagai bagian dari suatu bangsa merupakan kecakapan yang patut dimiliki oleh setiap individu di abad ke-21 ini (Hadiansyah, dkk, 2017). Karena keberagaman yang ada di Indonesialah yang membuat Indonesia terlihat indah dan keberagaman ini tidak boleh tenggelam. Kita sebagai warga negara Indonesia tentunya harus bertanggung jawab dalam menjaga keberagaman di tanah air tercinta ini.

Agar siswa mahir dalam membaca, menulis, dan bersikap akan kebudayaan yang ada, maka sistem pendidikan di Indonesia sudah menjalankan kurikulum 2013. "Dalam pendidikan, kurikulum diartikan sebagai pengaturan mengenai tujuan, isi, dan bahan pelajaran serta cara yang digunakan sebagai pedoman penyelenggaraan kegiatan pembelajaran untuk mencapai tujuan pendidikan tertentu" (UU Nomor 20 Tahun 2003, Pasal 1). Dengan adanya pengaturan tersebut, maka kegiatan pembelajaran akan lebih efektif dan efisien. "Kurikulum pada Sekolah Dasar/Madrasah Ibtidaiyah yang telah dilaksanakan sejak tahun ajaran 2013/2014 disebut kurikulum 2013" (Permendikbud Nomor 57 tahun 2014, Pasal 1).

Bukti nyata yang dapat dilihat dan dirasakan dari adanya Kurikulum 2013 yaitu penguasaan kompetensi terhadap materi yang diajarkan. Kompetensi adalah suatu hal kompleks yang didalamnya mengandung beberapa aspek (ranah), yaitu kompetensi sikap, kompetensi pengetahuan, dan kompetensi spiritual (Kosasih, 2018). Kompetensi bukanlah sebuah pengetahuan yang dapat dikatakan pasif. Contohnya jika ada seorang siswa yang pandai, namun ia tidak menggunakan kepandaiannya ke prilaku yang baik, maka kepandaian tersebut tidak ada gunanya. Kompetensi bukan sekadar mengetahui apa yang harus dilaksanakan, tetapi atas dasar apa yang sudah diketahui.

Pembelajaran IPS sesuai Kurikulum 2013, sikap, pegetahuan, serta keterampilan itu dikategorikan sebagai tingkat kemampuan untuk mencapai standar kompetensi lulusan yang harus dimiliki oleh siswa, yang diistilahkan sebagai kompetensi inti yang terdiri dari kompetensi inti sikap spiritual, kompetensi inti sikap sosial, kompetensi inti sikap pengetahuan, dan kompetensi inti keterampilan (Permendikbud Nomor 57, 2014). Melalui mata pelajaran IPS, siswa diarahkan untuk dapat menjadi warga negara Indonesia yang memiliki sikap demokratis, bertanggung jawab, dan warga dunia yang cinta damai. IPS adalah ilmu yang mempelajari berbagai displin ilmu yang terpadu berkaitan dengan manusia dan lingkungannya (Kristin, 2016). IPS merupakan bagian kurikulum sekolah yang berhubungan dengan peran manusia dalam masyarakat yang terdiri atas berbagai subjek sejarah, ekonomi, geograpi, sosiologi, antropologi, dan psikologi sosial.

Kegiatan literasi sangat penting dilakukan dan ditingkatkan di sekolah dasar untuk meningkatkan kemampuan siswa dalam mengahadapi permasalahan khususnya dalam pembelajaran IPS. Berdasarkan hasil observasi di SD gugus XIV Kecamatan Buleleng Kabupaten Buleleng, budaya literasi dilaksanakan dengan menyiapkan bahan bacaan berupa cerita rakyat, dongeng, buku tentang budaya indonesia, dan buku yang materinya tentang pelajaran yang ada di sekolah. Menurut para guru, kegiatan literasi masih belum optimal karena minimnya sumber yang digunakan untuk menerapkan budaya literasi. Sebab minimnya sumber yang digunakan adalah terbatasnya dana untuk mengembangkan kegiatan literasi di sekolah dan siswa sebagian besar suka memanfaatkan buku untuk hal yang tidak sepatutnya dilakukan, salah satu contohnya yaitu digunakan untuk bercanda bersama temannya sampai buku tersebut kurang 
layak untuk digunakan kembali. Kurang optimalnya pelaksanaan literasi tentunya berhubungan erat dengan kemampuan siswa untuk menalar maupun memahami karena di dalam gerakan literasi mampu melatih kemampuan menganalisis serta menemukan baik makna, tujuan, manfaat, atau permasalahan yang ada pada bacaan atau wacana tersebut. Peran guru dalam pembelajaran IPS adalah motivator dan fasilitator, yaitu guru melaksanakan pembelajaran IPS ini harus mampu membimbing dan mengarahkan siswa untuk memanfaatkan sumber belajar yang tersedia disekitarnya (Rustini, 2009). Guru sebagai pemberi bekal pengetahuan tentang manusia dan seluk beluk kehidupannya hendaknya mengarahkan siswa untuk tampil memecahkan masalah sosial disekitarnya.

Banyak siswa yang berpendapat bahwa IPS adalah pelajaran yang membosankan, baik dalam menerima penjelasan dari guru maupun membaca materi yang ada di buku ajar. Pembelajaran IPS seharusnya dibuat atau dirancang sesempurna mungkin agar siswa merasa senang serta tidak merasa bosan bahkan terpaksa untu belajar IPS. Siswa patutnya aktif baik secara fisik maupun mental dalam mengikuti pelajaran. Hal itu dapat terlaksana jika guru memberi kesempatan yang sebebas-bebasnya bagi murid untuk mengoptimalkan dan menggunakan semua indranya untuk belajar dengan cara mengaktifkan kerjasama, komunikasi, serta kolaborasi yang berhubungan dengan pelajaran dengan siswa lain atau temannya. Kegiatan tersebut dapat menguatkan daya ingat siswa, memudahkan dan mempercepat siswa untuk memahami segala sesuatu yang berhubungan dengan materi, meningkatkan keterampilan siswa, dan meningkatkan sikap positif siswa ke mata pelajaran IPS.

Pelajaran IPS sering dijumpai kalimat yang harus dipahami oleh siswa supaya dapat menyelesaikan permasalahannya. Bukan hanya memahami kalimat yang bersifat kualitatif saja, namun kalimat yang bersifat kuantitaf juga harus dipahami dalam pembelajaran IPS. Menurut hasil observasi yang didapat pada siswa kelas IV di Gugus XIV Kecamatan Buleleng, Kabupaten Buleleng permasalah yang telah ditemukan yaitu kurangnya budaya literasi yang terkait pada pembelajaran IPS.

Di bawah ini adalah tabel 1 rata-rata nilai UAS Mata Pelajaran IPS siswa kelas IV di Gugus XIV Kecamata Buleleng, Kabupaten Buleleng ahun Pelajaran 2018/2019.

\section{Tabel 1}

Nilai UAS IPS Siswa Kelas IV SD Gugus XIV Kecamatan Buleleng

\begin{tabular}{cccccc}
\hline \multirow{2}{*}{ No } & Nama Sekolah & \multirow{2}{*}{ Jumlah } & KKM & \multicolumn{2}{c}{ Jumlah } \\
\cline { 5 - 6 } & & & 69 & 17 & Tuntas \\
\hline 2. & SDN 1 Tukadmungga & 37 & 65 & 13 & 10 \\
\hline 3. & SDN 2 Tukadmungga & 23 & 69 & 11 & 10 \\
\hline 4. & SDN 3 Tukadmungga & 21 & 69 & 15 & 20 \\
\hline 5. & SDN 1 Pemaron & 35 & 60 & 13 & 10 \\
\hline & SDN 2 Pemaron & 23 & & 69 & 70 \\
\hline
\end{tabular}

Hasil wawancara dengan salah satu guru kelas IV SD di Gugus XIV mengatakan bahwa kemampuan siswa dalam mata pelajaran IPS memang masih rendah. Siswa biasanya hanya sekadar membaca tanpa memahami apa yang dipermasalahkan dalam soal itu.

Dari seluruh siswa kelas IV di Gugus XIV, hanya beberapa siswa saja yang memiliki kemampuan yang cukup baik dalam mata pelajaran IPS. Hal ini disebabkan karena kurangnya minat siswa dalam IPS. Bukan hanya itu, kurangnya kemampuan siswa dalam membudayakan literasi juga merupakan salah satu faktor yang menyebabkan nilai IPS siswa rendah.

Berdasarkan permasalahan tersebut, perlu dilakukan penelitian untuk mengetahui terdapat atau tidaknya hubungan antara budaya literasi baca tulis dan budaya dengan penguasaan kompetensi pengetahuan IPS siswa. Penelitian ini dilaksanakan dengan tujuan 
untuk mengetahui ada atau tidaknya korelasi yang signifikan antara literasi baca tulis dan budaya dengan penguasaan kompetensi pengetahuan IPS siswa kelas IV SD di Gugus XIV Buleleng Tahun Pelajaran 2018/2019.

\section{Metode}

Penelitian ini tergolong dalam jenis penelitian ex-post facto yaitu suatu penelitian yang mengkaji variabel terikat tanpa melakukan intervensi atau memanipulasi variabel bebas. Populasi penelitian ini adalah seluruh siswa kelas IV SD Gugus XIV Kecamatan Buleleng, yang berjumlah 139 orang. Teknik sampling yang digunakan adalah stratified proportional random sampling. Teknik sampling ini tidak berdasarkan pada strata, wilayah, tetapi didasarkan kuota yang telah ditentukan sebelumnya. Jadi jumlah sampel yang digunakan adalah 103 orang.

Variabel bebas dalam penelitian ini adalah literasi baca tulis $\left(\mathrm{X}_{1}\right)$ dan literasi budaya $\left(\mathrm{X}_{2}\right)$. Variabel terikatnya adalah penguasaan kompetensi pengetahuan IPS siswa (Y). Untuk memperoleh data variabel tersebut, digunakan tiga metode yaitu metode tes uraian, kuesioner, dan metode pencatatan dokumen. Data literasi baca tulis diperoleh dengan metode tes uraian dan literasi budaya diperoleh dengan kuesioner. Penguasaan kompetensi pengetahuan IPS siswa diperoleh dengan metode pencatatan dukumen. Jadi dalam penelitian ini digunakan satu jenis tes uraian yaitu tes uraian literasi baca tulis dan 1 jenis kuesioner yaitu kuesioner literasi budaya. Tes uraian dan kuesioner tersebut menggunakan skala lima. Dalam penelitian ini penguasaan kompetensi pengetahuan IPS siswa diperoleh dengan mengumpulkan dan mencatat nilai ulangan akhir semester I yang sudah direkap oleh guru kelas.

Teknik analisis data yang digunakan dalam penelitian ini yaitu teknik analisis statistik deskriptif, yang memaparkan mean, median, modus, standar deviasi, dan varian. Sebelum uji hipotesis dilakukan uji prasyarat. Uji prasyarat yang dilakukan ada lima yaitu uji normalitas, linearitas, dan multikolinearitas. Pertama, uji normalitas dilakukan untuk memenuhi persyaratan pertama yakni data yang dianalisis berdistribusi normal. Kedua, uji linearitas dilakukan untuk memenuhi persyaratan kedua yakni tiap-tiap variabel bebas dan terikat bersifat linear. Ketiga, uji multikolinearitas dilakukan untuk memenuhi persyaratan ketiga yaitu tidak terdapat hubungan yang tinggi antara variabel bebas.

Uji hipotesis penelitian dilakukan dengan dua analisis yaitu analisis regresi sederhana dan analisis regresi ganda. Pertama, teknik analisis regresi sederhana untuk hipotesis pertama dan kedua. Kedua analisis regresi ganda untuk hipotesis ketiga.

Hasil

\section{Hasil dan Pembahasan}

Deskripsi data literasi baca tulis, literasi budaya, dan penguasaan kompetensi pengetahuan IPS terdiri atas mean, median, dan modus. Hasil analisis data statistic deskriptif disajikan pada Tabel 2.

\section{Tabel 2}

Deskripsi data literasi baca tulis, literasi budaya, dan penguasaan kompetensi pengetahuan IPS

\begin{tabular}{|c|c|c|c|}
\hline $\begin{array}{c}\text { Statistik } \\
\text { Deskriptif }\end{array}$ & Literasi Baca Tulis & Literasi Budaya & $\begin{array}{c}\text { Penguasaan } \\
\text { Kompetensi } \\
\text { Pengetahuan IPS }\end{array}$ \\
\hline $\mathrm{N}$ & 103 & 103 & 103 \\
\hline Mean & 21.11 & 82.67 & 68.46 \\
\hline Median & 21 & 83 & 69 \\
\hline Modus & 18 & 81 & 62 \\
\hline Standar Deviasi & 7.33 & 20 & 16.67 \\
\hline Varian & 105.02 & 97.65 & 151.66 \\
\hline
\end{tabular}

Kadek Sri Trisna Devi , I Made Suarjana, Gede Wira Bayu. (2019).

Korelasi Antara Literasi Baca Tulis Dan Budaya Dengan Penguasaan Kompetensi Pengetahuan IPS Siswa Kelas IV. Mimbar PGSD Undiksha . Vol.u (v) pp. x-y. 
Untuk mengetahui tinggi rendahnya variabel literasi baca tulis dan literasi budaya, skor literasi baca tulis dan literasi budaya dikonversikan dengan menggunakan kriteria rata-rata ideal (Mi) dan standar deviasi (SDi). Rata-rata skor literasi baca tulis adalah 21.11 sedangkan skor literasi budaya 82.67. Berdasarkan hasil konversi, diketahui rata-rata skor literasi baca tulis berada diantara 18.34 - 25.67 sedangkan literasi budaya berada di antara 80-100. Sehingga kedua variabel bebas tersebut termasuk dalam kategori sedang. Untuk mengetahui tinggi rendahnya variabel penguasaan kompetensi pengetahuan IPS, nilai penguasaan kompetensi pengetahuan IPS dikonversikan dengan menggunakan kriteria. Rata-rata nilai penguasaan kompetensi pengetahuan IPS adalah 68.46. Berdasarkan hasil konversi, diketahui rata-rata nilai penguasaan kompetensi pengetahuan IPS berada diantara 55 - 69, sehingga termasuk dalam kategori sedang.

Pengujian selanjutnya yaitu uji prasyarat. Uji ini dilakukan sebelum pengujian hipotesis. Uji prasyarat meliputi uji normalitas sebaran data, uji linieritas, uji multikolinearitas, uji autokorelasi, dan uji heterokedastisitas. Pertama, Uji normalitas sebaran data dilakukan dengan menggunakan uji kolmogorov-smirnov yang dikenakan terhadap persepsi Literasi Baca Tuis (X1) dan Literasi Budaya (X2), dan Penguasaan Kompetensi Pengetahuan IPS (Y). Dari hasil perhitungan dengan menggunakan program SPSS 17.0 for windows diperoleh hasil seperti tabel 3 berikut.

\section{Tabel 3}

Hasil Uji Normalitas

\begin{tabular}{cccc}
\hline \multirow{2}{*}{ Variabel } & \multicolumn{3}{c}{ Kolmogorov-Smirnova $^{\text {a }}$} \\
\cline { 2 - 4 } & Statistic & $\mathrm{df}$ & Sig. \\
\hline Literasi Baca Tulis & .077 & 103 & .147 \\
\hline Literasi Budaya & .056 & 103 & $.200^{*}$ \\
\hline IPS & .049 & 103 & $.200^{*}$ \\
\hline
\end{tabular}

Hasil pengujian pada tabel 3 didapatkan bahwa nilai statistik ke tiga variabel pada kolom Kolmogorov-Smirnov lebih besar dari 0.05, maka dapat disimpulkan bahwa semua data dinyatakan normal. Kedua, Uji linieritas bertujuan untuk mengetahui apakah dua atau lebih variabel mempunyai hubungan yang linier atau tidak secara segnifikan. Uji ini biasanya digunakan sebagai prasyarat dalam analisis korelasi atau regresi linier. Pengujian pada SPSS 17.0 For Windows dengan menggunakan Test for Linearity dengan pada taraf signifikansi (Linearity) kurang dari 0.05. Dari hasil perhitungan dengan menggunakan program SPSS 17.0 for windows diperoleh hasil seperti tabel 4.

\section{Tabel 4}

Hasil Uji Linieritas

\begin{tabular}{rccc}
\hline Variabel Uji Linieritas & Keterangan & Sig. & Simpulan \\
\hline \multirow{2}{*}{ IPS * Literasi Baca Tulis } & Linearity $(\mathrm{p}<0.05)$ & .030 & Linier \\
\cline { 2 - 4 } & Deviation from Linearity $(\mathrm{p}>0.05)$ & .368 & Berarti \\
\hline \multirow{2}{*}{ IPS * Literasi Budaya } & Linearity $(\mathrm{p}<0.05)$ & .042 & Linier \\
\cline { 2 - 4 } & Deviation from Linearity $(\mathrm{p}>0.05)$ & .206 & Berarti \\
\hline
\end{tabular}

Analisis yang telah dilakukan pada tabel 4, didapatkan signifikansi Linearity kurang dari 0.05 sehingga kedua variabel bebas tersebut dengan penguasaan kompetensi pengetahuan IPS memiliki hubungan yang linier. Sedangkan signifikansi Deviation from Linearity lebih besar dari $>0.05$ kedua variabel bebas tersebut dengan penguasaan kompetensi pengetahuan IPS memiliki hubungan yang berarti. 
Ketiga, Uji multikolinieritas bertujuan untuk menguji apakah pada model regresi ditemukan adanya korelasi antar variabel bebas. Dalam model regresi yang baik seharusnyatidak terjadi korelasi antara variabel bebas. Uji multikolinieritas dilakukan dengan melihat nilai tolerance dan variance inflation factor (VIF). apabila nilai tolerance value lebih besar dari 0.1 atau nilai VIF kurang dari 10, maka dikatakan tidak ada multikolinieritas, hal ini dapat dilihat pada Tabel 5 .

Tabel 5

Hasil Uji Multikolinieritas

\begin{tabular}{|c|c|c|c|}
\hline \multicolumn{4}{|c|}{ Coefficients $^{a}$} \\
\hline & \multirow{2}{*}{ Model } & \multicolumn{2}{|c|}{ Collinearity Statistics } \\
\hline & & Tolerance & VIF \\
\hline \multicolumn{4}{|c|}{ (Constant) } \\
\hline \multirow[t]{2}{*}{1} & Literasi Baca Tulis & .286 & 3.501 \\
\hline & Literasi Budaya & .286 & 3.501 \\
\hline
\end{tabular}

Hasil pengujian yang diperlihatkan tabel 5, nilai tolerance variabel bebas tidak ada yang kurang dari $10 \%$ dan lebih besar dari $10 \%$ atau 0.1 serta nilai VIF semuanya kurang dari 10 yang berarti tidak terdapat multikolinieritas antar variabel inependen dalam model regresi yang digunakan.

Setelah melaksanakan uji prasyarat, dilanjutkan dengan melakukan pengujian hipotesis. Hasil uji hipotesis dalam penelitian ini membuktikan bahwa: pertama, $t$ hitung (2.214) > t tabel (1.660), maka HO ditolak berarti secara statistik ada hubungan nyata dan positif antara Literasi Baca Tulis (X1) dengan Penguasaan Kompetensi Pengetahuan IPS (Y). Dari hasil regresi juga dapat diinterprestasikan bahwa ada hubungan yang nyata antara Literasi Baca Tulis (X1) dengan Penguasaan Kompetensi Pengetahuan IPS (Y). Hal ini diperkuat dengan nilai signifikansi 0.029 yang lebih kecil dari 0.05

Kedua, t hitung (3.565) > t tabel (1.660), maka H0 ditolak berarti secara statistik ada hubungan nyata dan positif antara Literasi Budaya (X2) dengan Penguasaan Kompetensi Pengetahuan IPS (Y). Dari hasil regresi juga dapat diinterprestasikan bahwa ada hubungan yang nyata antara Literasi Budaya (X2) dengan Penguasaan Kompetensi Pengetahuan IPS (Y). Hal ini diperkuat dengan nilai signifikansi 0.001 yang lebih kecil dari 0.05

Ketiga, hasil analis menunjukkan bahwa F hitung > F tabel yaitu $32.360>3.09$ maka "H" _"0" ditolak dan "H" _"1" diterima. Hal ini berarti variabel bebas yang terdiri dari Literasi Baca Tulis (X1) dan Literasi Budaya (X2) secara serempak berhubungan signifikan dengan Penguasaan Kompetensi Pengetahuan IPS (Y). hal ini juga diperkuat dengan tingkat signifikansi 0.00 yang lebih kecil dari 0.05 .

\section{Pembahasan}

Pertama, Bersumber pada hasil analisis yang telah dilakukan, dapat disimpulkan bahwa Hipotesis pertama yang berbunyi "terdapat hubungan yang positif antara literasi abaca tulis dengan Penguasaan Kompetensi Pengetahuan IPS Siswa Kelas IV SD di Gugus XIV Kecamatan Buleleng Tahun Pelajaran 2018/2019" dinyatakan diterima, hal ini ditunjukkan oleh persamaan regresi $\hat{Y}=41.132+0.980 \mathrm{X} 1$ dengan Fhitung $=46.604$. Dalam penelitian ini ditemukan korelasi yang positif dan signifikan yang berarti semakin tinggi literasi baca tulis siswa maka semakin tinggi pula penguasaan kompetensi pengetahuan IPS siswa. Hal ini dikarenakan literasi baca tulis memiliki kemampuan untuk memahami isi teks tertulis, baik yang tersirat maupun tersurat, dan menggunakannya untuk mengembangkan pengetahuan dan potensi diri. Selain itu, 
dalam melaksanakan kegiatan literasi baca tulis siswa mampu untuk menuangkan gagasan dan ide ke dalam tulisan dengan susunan yang baik untuk berpartisipasi di lingkungan sosial (Saryono, dkk, 2017). Oleh karena itu, semakin sering melaksanakan literasi baca tulis dengan sungguh-sunggu, maka semakin tinggi pula penguasaan kompetensi pengetahuan IPS siswa. Sumbangan literasi baca tulis yang diberikan siswa terhadap penguasaan kompetensi pengetahuan IPS sebesar 31.6\%.

Hasil penelitian ini sejalan dengan penelitian terdahulu dari hasil penelitian Rusminati dan Cholifah (2018) yang meneliti tentang Korelasi Penerapan Gerakan Literasi Sekolah (GLS) dengan Kemampuan Menyelesaikan Soal Cerita Matematika. Tinggi rendahnya kemampuan menyelesaikan soal cerita matematika siswa bergantung pada GLS yang diterapkan guru di sekolah. Berdasarkan hasil analisis dan temuan dalam penelitian lain yang sesuai dengan penelitian ini, dapat disimpulkan bahwa terdapat hubungan yang positif antara literasi abaca tulis dengan Penguasaan Kompetensi Pengetahuan IPS Siswa Kelas IV SD di Gugus XIV Kecamatan Buleleng Tahun Pelajaran 2018/2019.

Kedua, Terdapat Korelasi Antara Literasi Budaya dengan Penguasaan Kompetensi Pengetahuan IPS Siswa Kelas IV SD di Gugus XIV Kecamatan Buleleng Tahun Pelajaran 2018/2019

Bersumber pada hasil analisis yang telah dilakukan, dapat disimpulkan bahwa Hipotesis pertama yang berbunyi "terdapat hubungan yang positif antara literasi budaya dengan Penguasaan Kompetensi Pengetahuan IPS Siswa Kelas IV SD di Gugus XIV Kecamatan Buleleng Tahun Pelajaran 2018/2019" dinyatakan diterima, hal ini ditunjukkan oleh persamaan regresi $\hat{Y}$ $=27.455+0.436 \mathrm{X} 1$ dengan Fhitung $=57.594$. Dalam penelitian ini ditemukan korelasi yang positif dan signifikan yang berarti semakin literasi baca tulis siswa maka semakin tinggi pula penguasaan kompetensi pengetahuan IPS siswa. Hal ini dikarenakan di dalam melaksanakan kegiatan literasi budaya, siswa menjadi mampu dalam bersikap terhadap lingkungan sosialnya sebagai bagian dari suatu budaya (Hadiansyah, dkk, 2017). Oleh karena itu, semakin rutin melaksanakan literasi budaya dengan sungguh-sunggu, maka semakin tinggi pula penguasaan kompetensi pengetahuan IPS siswa. Sumbangan literasi baca tulis yang diberikan siswa terhadap penguasaan kompetensi pengetahuan IPS sebesar $36.3 \%$.

Hasil penelitian ini sejalan dengan penelitian terdahulu dari hasil penelitian Faradina (2017) yang meneliti tentang Pengaruh Program Gerakan Literasi Sekolah Terhadap Minat Baca Siswa di SD Islam Terpadu Muhammadiyah An-Najah Jatinom Klaten. Tinggi rendahnya minat baca siswa bergantung pada program gerakan literasi sekolah yang diterapkan guru di sekolah. Berdasarkan hasil analisis dan temuan dalam penelitian lain yang sesuai dengan penelitian ini, dapat disimpulkan bahwa terdapat hubungan yang positif antara literasi budaya dengan Penguasaan Kompetensi Pengetahuan IPS Siswa Kelas IV SD di Gugus XIV Kecamatan Buleleng Tahun Pelajaran 2018/2019.

Ketiga, Terdapat Korelasi Antara Literasi Baca Tulis dan Budaya dengan Penguasaan Kompetensi Pengetahuan IPS Siswa Kelas IV SD di Gugus XIV Kecamatan Buleleng Tahun Pelajaran 2018/2019

Bersumber pada hasil analisis yang telah dilakukan, dapat disimpulkan bahwa Hipotesis pertama yang berbunyi "Terdapat Hubungan yang Positif antara Literasi Baca Tulis Dan Budaya Dengan Penguasaan Kompetensi Pengetahuan IPS Siswa Kelas IV SD di Gugus XIV Kecamatan Buleleng Tahun Pelajaran 2018/2019" dinyatakan diterima, hal ini ditunjukkan oleh persamaan regresi $\mathrm{Y}=27.894+0.447 \mathrm{X} 1+0.299 \mathrm{X} 2$ dengan Fhitung $=32.360$. Dalam penelitian ini ditemukan korelasi yang positif dan signifikan yang berarti semakin tinggi literasi baca tulis dan budaya siswa maka semakin tinggi pula penguasaan kompetensi pengetahuan IPS siswa. Hal ini dikarenakan literasi baca tulis memiliki kemampuan untuk memahami isi teks tertulis, baik yang tersirat maupun tersurat, dan menggunakannya untuk mengembangkan pengetahuan dan potensi diri. Dalam melaksanakan kegiatan literasi baca tulis siswa juga mampu untuk menuangkan gagasan dan ide ke dalam tulisan dengan susunan yang baik untuk berpartisipasi 
di lingkungan sosial (Saryono, dkk, 2017). Selain literasi baca tulis, literasi budaya juga berperan penting dalam meningkatkan penguasaan kompetensi pengetahuan IPS siswa. Hal ini dikarenakan di dalam melaksanakan kegiatan literasi budaya, siswa menjadi mampu dalam bersikap terhadap lingkungan sosialnya sebagai bagian dari suatu budaya (Hadiansyah, dkk, 2017). Semakin rutin melaksanakan literasi budaya dengan sungguh-sunggu, maka semakin tinggi pula penguasaan kompetensi pengetahuan IPS siswa. Sumbangan literasi baca tulis dan literasi budaya yang diberikan siswa terhadap penguasaan kompetensi pengetahuan IPS sebesar $39.3 \%$.

Hasil penelitian ini sejalan dengan penelitian terdahulu dari hasil penelitian Sari (2018) yang meneliti tentang Hubungan Antara Kemampuan Literasi dengan Kompetensi Inti Pengetahuan Bahasa Indonesia Siswa Kelas V Sd Gugus Letkol Wisnu Denpasar Utara Tahun Pelajaran 2017/2018. Tinggi rendahnya kompetensi inti pengetahuan bahasa indonesia siswa bergantung pada kemampuan literasi yang diterapkan guru di sekolah. Berdasarkan hasil analisis dan temuan dalam penelitian lain yang sesuai dengan penelitian ini, dapat disimpulkan bahwa terdapat hubungan yang positif antara literasi baca tulis dan budaya dengan penguasaan kompetensi pengetahuan IPS siswa kelas IV SD di gugus XIV Kecamatan Buleleng tahun pelajaran 2018/2019.

\begin{tabular}{lccccc}
\hline Site & $\begin{array}{c}\mathrm{TiO}_{2} \\
(\mathrm{wt} \%)\end{array}$ & $\begin{array}{c}\mathrm{Al}_{2} \mathrm{O}_{3} \\
(\mathrm{wt} \%)\end{array}$ & $\begin{array}{c}\mathrm{MnO} \\
(\mathrm{wt} \%)\end{array}$ & $\begin{array}{c}\mathrm{MgO} \\
(\mathrm{wt} \%)\end{array}$ & $\begin{array}{c}\mathrm{Na}_{2} \mathrm{O} \\
(\mathrm{wt} \%)\end{array}$ \\
\hline GIJ & 0.5 & 16.4 & 0.19 & 2.74 & 3.00 \\
GPW & 0.78 & 19.0 & 0.18 & 4.57 & 2.55 \\
GSR & 0.62 & 16.3 & 0.17 & 3.09 & 3.09 \\
KLB & 0.67 & 15.7 & 0.14 & 5.07 & 2.59 \\
KSG & 1.90 & 17.1 & 0.15 & 3.79 & 3.33 \\
PWH & 0.58 & 20.9 & 0.12 & 1.55 & 3.00 \\
SKP & 0.68 & 17.8 & 0.16 & 3.12 & 2.75 \\
\hline
\end{tabular}

Tabel dibuat dengan lebar garis 1 pt dan tables caption (keterangan tabel) diletakkan di atas tabel ditulis menggunakan huruf Cambria ukuran 9 dengan rata kiri dengan keterangan tabel dicetak tebal. Keterangan tabel yang terdiri lebih dari 2 baris ditulis menggunakan spasi 1 .

Garis-garis tabel diutamakan garis horizontal saja sedangkan garis vertikal dihilangkan

\section{Simpulan}

Berdasarkan hasil analisis yang telah diuraikan sebelumnya maka dapat diambil kesimpulan sebagai berikut. Pertama, Hasil analisis deskriptif menemukan bahwa Literasi Baca Tulis berada pada kategori sedang dengan rata-rata 21.11, Literasi Budaya berada pada kategori sedang dengan rata-rata 88.67, dan penguasaan kompetensi pengetahuan IPS berada pada kategori cukup dengan rata-rata 68.46.

Kedua, Penelitian ini menemukan bahwa ada hubungan signifikan dan positif antara variabel X1 denganY. Ini ditunjukkan karena $r$ hitung (0.562) $>r$ tabel (0.195) adalah signifikan, demikian juga $\mathrm{t}$ hitung (2.214) $>\mathrm{t}$ tabel (1.660). Dari hasil regresi ini juga dapat diinterpretasikan bahwa ada hubungan yang nyata antara variabel X1 dengan Y. Hal ini diperkuat dengan nilai signifikansi 0.00 yang lebih kecil dari 0.05 dengan besarnya hubungan sebesar $31.6 \%$. Ini artinya bahwa sebesar $68.4 \%$ ada faktor lain yang berhubungan dengan penguasaan kompetensi pengetahuan IPS (Y).

Ketiga, Penelitian ini menemukan bahwa ada hubungan signifikan dan positif antara variabel X2 denganY. Ini ditunjukkan karena $r$ hitung (0.603) $>r$ tabel $(0.195)$ adalah signifikan, demikian juga $\mathrm{t}$ hitung (3.565) $>\mathrm{t}$ tabel (1.660). Dari hasil regresi ini juga dapat diinterpretasikan bahwa ada hubungan yang nyata antara variabel X2 dengan Y. Hal ini diperkuat dengan nilai signifikansi 0.00 yang lebih kecil dari 0.05 dengan besarnya hubungan sebesar $36.3 \%$. Ini artinya bahwa sebesar $63.7 \%$ ada faktor lain yang berhubungan dengan penguasaan kompetensi pengetahuan IPS (Y). 
Keempat, Secara simultan ditemukan bahwa ada hubungan antara Literasi Baca Tulis (X1) dan Literasi Budaya (X2) dengan Penguasaan Kompetensi Pengetahuan IPS. Hal ini dapat dilihat bahwa $r$ hitung (0.627) > $r$ tabel (0.195) demikian juga berdasarkan hasil pengujian dengan Uji $F$ (secara Simultan), maka dapat diketahui bahwa variabel X1 dan X2 secara serempak berhubungan signifikan terhadap variabel $\mathrm{Y}$. Ini diperkuat dengan hasil $\mathrm{F}$ hitung $>\mathrm{F}$ tabel yaitu $32.360>3.09$. Hal ini juga diperkuat dengan tingkat signifikansi 0.00 yang lebih kecil dari 0.05 dengan besarnya hubungan sebesar 39.3\%. Ini artinya bahwa sebesar $60.7 \%$ ada faktor lain yang berhubungan dengan penguasaan kompetensi pengetahuan IPS (Y). 


\section{Daftar Pustaka}

Faradina, N. 2017. "Pengaruh Program Gerakan Literasi Sekolah Terhadap Minat Baca Siswa di SD Islam Terpadu Muhammadiyah An-Najah Jatinom Klaten". Hanata Widya, Volume 6, $\begin{array}{lllll}\text { Nomor } & 8 & \text { (hlm } & 60) & \text { Tersedia }\end{array}$ http://journal.student.uny.ac.id/ojs/index.php/fipmp/article/view/9280 (diakses pada tanggal 20 januari 2019).

Gipayana, M. 2004. "Pengajaran Literasi dan Penilaian Portofolio dalam Konteks Pembelajaran Menulis di SD". Jurnal Ilmu Pendidikan, Volume 11, Nomor 1. Tersedia pada www.academia.edu/download/ 48212090/87-3399-1-PB.pdf. (diakses pada tanggal 21 januari 2019).

Hadiansyah, Firman, dkk. 2017. Literasi Budaya dan Kewargaan. Jakarta: Kementerian Pendidikan dan Kebudayaan.

Kosasih, E. 2018. Strategi Belajar dan Pembelajaran Implementasi Kurikulum 2013. Bandung: Yrama Widya.

Kristin, F. 2016. "Efektivitas Model Pembelajaran Kooperatif Tipe Stad Ditinjau dari Hasil Belajar IPS Siswa Kelas 4 SD”. Scholaria: Jurnal Pendidikan dan Kebudayaan, Volume 6, Nomor 2. Tersedia pada http://ejournal.uksw.edu/ scholaria/article/view/230. (diakses pada tanggal 21 januari 2019).

Mundziroh, S. 2013. "Peningkatan Kemampuan Menulis Cerita dengan Menggunakan Metode Picture And Picture Pada Siswa Sekolah Dasar". Jurnal Basastra, Volume 2, Nomor 1. Tersedia pada http://www.jurnal. fkip.uns.ac.id/index.php/bhs_indonesia/article/view/2148/1563. (diakses pada tanggal 21 januari 2019).

Permendikbud Nomor 57 Tahun 2014 tentang Kurikulum 2013 Sekolah Dasar/Madrasah Ibtidaiyah, 2014. Jakarta: Departemen Pendidikan dan Kebudayaan.

Rusminati, Susi Hermin dan Cholifah Tur Rosidah. 2018. "Korelasi Penerapan Gerakan Literasi Sekolah (GLS) dengan Kemampuan Menyelesaikan Soal Cerita Matematika Siswa Di SDN Kebondalem Mojosari dan SDN Ketabang Surabaya". Jurnal Inventa, Volume 2, Nomor 2 (hlm 97). Tersedia pada http://jurnal.unipasby.ac.id/index.php/jurnal_inventa/article /view/1710 (diakses tanggal 20 Januari 2019).

Rustini, T. 2009. "Penerapan Model Inkuiri dalam Meningkatkan Pembelajaran IPS di Kelas IV Sekolah Dasar". EduHumaniora Jurnal Pendidikan Dasar, Volume 1, Nomor 1. Tersedia pada http://ejournal.upi .edu/index.php/eduhumaniora/article/view/2721. (diakses tanggal 20 Januari 2019).

Sari, Y. 2018. "Hubungan Antara Kemampuan Literasi dengan Kompetensi Inti Pengetahuan Bahasa Indonesia Siswa Kelas V SD Gugus Letkol Wisnu Denpasar Utara Tahun Pelajaran 2017/2018". Indonesian Journal Of Educational Research and Review, Volume 1, Nomor 2 (hlm 94). Tersedia pada https://ejournal.undiksha.ac.id/index.php/IJERR/article/ view/14708 (diakses tanggal 28 Januari 2019).

Saryono, Djoko, dkk. 2017. Literasi Baca Tulis. Jakarta: Kementerian Pendidikan dan Kebudayaan.

UU Nomor 20 Tahun 2003 tentang Sistem Pendidikan Nasional, 2003. Jakarta: Departemen Pendidikan dan Kebudayaan. 
Widodo, Wellanda, dkk. 2016. "Penerapan Metode Pemberian Tugas Dan Resitasi Dalam Upaya Meningkatkan Kemampuan Menulis Surat Siswa Kelas X D Administrasi Perkantoran Smk Wikarya Karanganyar Tahun Ajaran 2014/2015". Jurnal Informasi Dan Komunikasi Administrasi Perkantoran, Volume 1, No. 1. Tersedia pada www.jurnal.fkip.uns.ac.id/ index.php/jikap/article/download/9796/7239. (diakses pada tanggal 21 januari 2019).

Wijaya, Etistika Yuni, dkk. 2016. "Transformasi Pendidikan Abad 21 Sebagai Tuntutan Pengembangan Sumber Daya Manusia Di Era Global". Prosiding Seminar Nasional Pendidikan Matematika 2016 Universitas Kanjuruhan Malang, Volume 1. Tersedia pada http://repository.unikama. ac.id/840/32/263-278transformasi pendidikan abad21 sebagai tuntutan pengembangan sumberdayamanusia di era global.pdf. (diakses pada tanggal 21 Januari 2019).

Winaya, I M. A. 2018. “Efektifitas Implementasi Model Pembelajaran Tematik Berbasis Teknohumanistik Dalam Pengembangan Nilai-nilai Karakter Pada Siswa SD Dwijendra Denpasar". Jurnal Ilmiah Ilmu Sosial, Volume 4, Nomor 2. Tersedia pada https://ejournal.undiksha.ac.id/index. php/JIIS/index. (diakses pada tanggal 21 januari 2019). 